\title{
A 100-Year Review: Progress on the chemistry of milk and its components ${ }^{1}$
}

\author{
John A. Lucey, ${ }^{2}$ Don Otter, and David S. Horne \\ Center for Dairy Research, University of Wisconsin-Madison, Madison 53706
}

\begin{abstract}
Understanding the chemistry of milk and its components is critical to the production of consistent, highquality dairy products as well as the development of new dairy ingredients. Over the past $100 \mathrm{yr}$ we have gone from believing that milk has only 3 protein fractions to identifying all the major and minor types of milk proteins as well as discovering that they have genetic variants. The structure and physical properties of most of the milk proteins have been extensively studied. The structure of the casein micelle has been the subject of many studies, and the initial views on submicelles have given way to the current model of the micelle as being assembled as a result of the concerted action of several types of interactions (including hydrophobic and the formation of calcium phosphate nanoclusters). The benefits of this improved knowledge of the type and nature of casein interactions include better control of the cheesemaking process, more functional milk powders, development of new products such as cream liqueurs, and expanded food applications. Increasing knowledge of proteins and minerals was paralleled by developments in the analysis of milk fat and its synthesis together with greater knowledge of its packaging in the milk fat globule membrane. Advances in analytical techniques have been essential to the isolation and characterization of milk components. Milk testing has progressed from gross compositional analyses of the fat and total solids content to the rapid analysis of milk for a wide range of components for various purposes, such as diagnostic issues related to animal health. Up to the 1950 s, research on dairy chemistry was mostly focused on topics such as protein fractionation, heat stability, acid-base buffering, freezing point, and the nature of the calcium phosphate present in milk. Between the 1950s and 1970s, there was a major focus on identifying all the main protein types, their sequences, variants, association behavior, and other physical prop-
\end{abstract}

\footnotetext{
Received May 29, 2017.

Accepted July 15, 2017.

${ }^{1}$ This review is part of a special issue of the Journal of Dairy Science commissioned to celebrate 100 years of publishing (1917-2017).

${ }^{2}$ Corresponding author: jlucey@cdr.wisc.edu
}

erties. During the 1970s and 1980s, one of the major emphases in dairy research was on protein functionality and fractionation processes. The negative cloud over dairy fat has lifted recently due to multiple reviews and meta-analyses showing no association with chronic issues such as cardiovascular disease, but changing consumer misconceptions will take time. More recently, there has been a great deal of interest in the biological and nutritional components in milk and how these materials were uniquely designed by the cow to achieve this type of purpose.

Key words: milk protein, functionality, dairy chemistry

\section{INTRODUCTION}

Several critical reviews have been published in the Journal of Dairy Science on the progress of milk chemistry and its components. Jenness (1956) reviewed the previous $50 \mathrm{yr}$ of progress in the Journal of Dairy Science edition commemorating the 50th anniversary of the formation of ADSA, and Harper (1981) and Brunner (1981) updated key achievements and milestones for the 75th anniversary edition. Many of the key historical references can be found in these reviews, and only selected references are highlighted in this review. Jenness (1956) stated, "Much of the progress made in the last half-century in the basic knowledge of the chemistry of milk has consisted of filling in details in a picture whose broad outlines were already delineated." In the past 50 yr, dairy chemistry has moved on from the previous emphasis on organic chemistry to studies related to biochemistry, physical chemistry, nutrition, processinginduced reactions, physiology, genetics, genomics, and structural biology.

Another key factor in progressing our knowledge in the milk composition field was the creation of the ADSA Committee on Milk Protein Nomenclature, Classification, and Methodology, which published its first report in 1956 (Jenness et al., 1956) in the Journal of Dairy Science. That report recognized a total of 8 milk proteins, whereas in the 2004 report (6th ed.; Farrell et al., 2004), 13 major milk proteins were identified along with their many genetic variants. The report also clarified that some of the $\mathrm{CN}$ have different levels of phosphorylation and were not in fact new types of pro- 
teins. This committee recognized that older empirically named protein fractions were often in fact mixtures, and to avoid confusion they published their preferred nomenclature for these new individual components. In subsequent decades this committee continued to publish updated reports, which also appeared in the Journal of Dairy Science. The work of this committee helped standardize the naming of various milk protein fractions and variants, correcting errors and incorporating primary structures as sequencing data became available. There are likely hundreds of proteins present in milk at concentrations as low as microgram per liter levels, and many of these proteins are likely associated with minor components, such as the lipoprotein membranes.

Looking back over the past 100 yr (see Appendix Table A1), we can note that by 1917 (when the Journal of Dairy Science was first published) considerable information was already available on the gross chemical composition of milk as well as seasonal or breed variation. We refer to Dairy Chemistry by Richmond (1914) to benchmark what was known about dairy chemistry around 100 yr ago. Many minor components have since been discovered and characterized, including many vitamins, enzymes, and trace elements. Over the past $50 \mathrm{yr}$ numerous studies have been conducted on the effect of feed and lactation on the detailed composition of milk as well as the effect on functional properties such as rennet coagulation. In 1917, milk proteins were considered to consist of only 3 main fractions: $\mathrm{CN}$, lactalbumin, and lactoglobulin. Over the next $40 \mathrm{yr}$ a major focus was on the fractionation of milk proteins by a range of experimental methods and new analytical approaches.

Over the past 30 yr there has been growing awareness of the incredible diversity of nutrients in milk as well as how these milk components provide various types of important bioactivities well beyond just providing nutrition. This focus on the nutritional diversity of milk has been assisted by developments such as improved analytical techniques that facilitated lower detection levels, the exploitation of a range of -omic techniques, use of a wide range of in vitro and in vivo models, and greater knowledge of the composition of human milk as well as the milks of other breeds.

In 1917, knowledge on how milk components were synthesized within the mammary gland was limited. It is now well established that most major milk constituents are synthesized in the mammary gland from components obtained from the blood. However, considerable modification occurs in the mammary gland, including creation of the finished structure (e.g., CN micelle, triglycerides, lactose; Bauman et al., 2006). In his review for the Journal of Dairy Science issue commemorating the 75th anniversary of the ADSA, Brunner (1981) warned young scientists reviewing the thousands of scientific papers published in dairy chemistry about being lured into complacency thinking everything worth knowing has been investigated. He stated, "Nothing could be further from the truth!" He argued that we did not fully understand the milk protein system and its organization, the complexities of milk synthesis at the cellular level, or the purpose of many components. Although much has been learned since that review, we still do not fully understand the very complex biological structures present in milk.

\section{A CENTURY OF PROGRESS IN DAIRY CHEMISTRY}

\section{Advances in Analytical Techniques}

Progress in identifying milk components and describing their detailed physical and chemical properties is linked to the development of new analytical techniques. Many advances in analytical equipment have been made over the past $100 \mathrm{yr}$, including analytical centrifugation, electrophoresis, thin-layer chromatography, GC, AA sequencing, electron microscopy, dynamic light scattering, neutron and X-ray scattering, rheology, MS, genomic approaches, and so on. For example, as electron microscopy developed in the 1940s it quickly showed that CN particles are large and mostly spherical (Nitschmann, 1949). Later, with improvements in electron microscopy, researchers reported that the surface was not entirely smooth, which contributed to the belief that micelles were made up of subunits. Recently, topographical electron microscopy techniques have given a 3-dimensional picture of the inside of the $\mathrm{CN}$ micelle, showing large voids mostly occupied by water.

The development of analytical centrifugation helped Waugh and colleagues in their classic studies of CN association (Waugh, 1971). It is notable that dairy scientists have routinely collaborated with other basic scientists to explore new physical techniques as they were being developed. For example, the first reliable measurements of the size distribution of $\mathrm{CN}$ micelles used dynamic light scattering. Many dairy scientists have heard about Pieter Walstra's famous experiment in which he demonstrated that rennet action reduced the average micelle size and thus provided experimental evidence for the presence of $\mathrm{k}$-CN hairs on the micelle surface (Walstra et al., 1981). This development came about because Victor Bloomfield was already using dynamic light scattering to measure micelle size, and Walstra came along one afternoon to talk to him while he was on sabbatical at the University of Minnesota. A few years later David Horne, again using dynamic light scattering, demonstrated the collapse of the hairy 
layer when micelles were diluted into ethanol solutions. This paper, submitted to the journal recognized as the biophysics behemoth of the time, was rejected. However, due to a lapse in standard procedure, the entire correspondence including the editorial comments on reviewers' opinions was sent to the author. Bloomfield and Walstra had been consulted. Bloomfield pleaded pressure of work and returned the manuscript without review, but Walstra positively endorsed the paper. The editor then strangely decided to reject the paper because he believed that Walstra liked it only because it supported his theories. The paper was subsequently submitted to another journal, where it was published with minor cosmetic changes. This illustrates that the scientific review process is not perfect but that discoveries do still get through! Further confirmation that renneting reduces micelle size was facilitated by the introduction of diffusing wave spectroscopy by Horne. This enabled researchers to look at the initial stages of micelle aggregation without having to dilute the milk and perhaps alter reaction conditions or disturb the CN particle structure.

Starting in the 1980s and continuing to the present, a range of powerful techniques such as neutron reflectivity have helped contribute to our understanding of how $\mathrm{CN}$ and other proteins bind to interfaces and thus their behavior as emulsifiers. Those insights also played a critical role in the understanding of the hydrophobic behavior of individual $\mathrm{CN}$ during micelle assembly in the mammary gland. Neutron and x-ray scattering have also been widely applied to probe internal micelle structure. Rheology and viscosity measurements changed the face of milk gel studies, particularly as rheometers became more sensitive and the transition from fluid to gel could be carefully followed (Lucey, 2002). The problem remains that theories on bonding and gel structure that are relevant for milk gels have yet to catch up with the ability to measure gel development.

What we have not seen yet are nuclear magnetic resonance (NMR) studies of whole-protein interactions. As this technique gets more powerful, hopefully such studies will be able to identify peptides or AA directly involved in interactions. For example, Pro should have a distinctive signature that could be influenced when interactions across the heterocyclic ring occur with, say, an aromatic partner. There are bound to be restrictions on how the ring puckers or how its mobility is influenced that would be picked up by NMR. Maybe that is something we will see in the future.

Mass spectrometry coupled with liquid chromatography was first widely used for the study of dairy components in the 1990s. One of the first novel insights from this technique was that lactose molecules could become attached to milk proteins via the Maillard reac- tion (called lactosylation) during the prolonged storage of milk powders. Mass spectrometry has become a key analytical tool for identifying bioactive peptides, minor components, and nature of whey protein aggregates; confirming levels of phosphorylation in the $\mathrm{CN}$; and countless other applications in dairy chemistry.

Powerful biophysical techniques such as circular dichroism and Raman spectroscopy have been used in the search for possible secondary structure in the CN. Harry Farrell and the group at the USDA extensively explored this topic and tried to use these results for molecular modeling of the CN (e.g., Kumosinski et al., 1993). More generally, and not just with the CN, computational techniques are advancing by leaps and bounds. Perhaps these techniques will get around to tackling hydrophobic interactions in more depth. One problem is the range of time scales involved (from the rapid exchange and movement of water molecules involved in hydration to the slow diffusional motion, perhaps restricted, of peptide chains) and the range of sizes (from water molecules to peptides and proteins). Knowledge of the nature of hydrophobicity and water distribution around AA is moving forward all the time and will help us better understand the structure of CN micelles.

In 1917, many dairy laboratories used lactometers to calculate TS from fat content (measured by the Babcock test) and specific gravity. The first rapid analyzer for measuring the fat content of milk was developed in 1959 (Haugaard and Pettinati, 1959). This instrument became known as the Milko Tester. It measured the light scattered by fat globules in a diluted milk sample, and the milk was homogenized in the instrument to ensure that scattering was not affected by different-size fat particles. Other later milk fat and protein analysis methods included dye binding and spectrometric methods.

Initially developed in the 1960s, infrared spectroscopy (middle- and near-infrared) had become popular by the 1980s for the rapid analysis of major components (e.g., fat, protein, lactose, and moisture) in dairy products. This technique benefited from advances in computers and statistics (e.g., multivariate data analysis techniques) to determine individual components from the spectral data. Regular calibration against standards of known composition (usually determined by a traditional reference method) is still required. Milk testing is now routinely used for regulatory purposes such as detection of antibiotics or adulteration (e.g., added water) and for payments to farmers based on milk quality (e.g., fat, protein, somatic cells). Routine milk compositional testing (including MUN) is performed by dairy processing plants as well as by dairy testing associations to help farmers create data to inform management deci- 
sions about improving their herds. Recently there has been growing interest in applying this type of technique for inline testing of raw milk quality at the farm level or even for analysis of an individual cow's milk.

\section{Milk Proteins}

Several key reviews on the properties of milk proteins and CN micelles have been published, and many references on this subject can be found in Gordon (1971), Waugh (1971), Farrell (1973), Walstra (1990), Swaisgood (1993), Horne (2006), and Fox and Brodkorb (2008).

Fractionation and Identification of Individual Milk Proteins. About 100 yr ago, scientists such as Linderstrøm-Lang first discovered that $\mathrm{CN}$ was in fact a heterogeneous collection of various fractions. Linderstrøm-Lang (1929) showed that isoelectrically precipitated acid $\mathrm{CN}$ in fact comprised 3 major fractions, later designated as $\alpha_{-}, \beta-$, and $\gamma-\mathrm{CN}$ (Mellander, 1939). Previously, researchers thought that the CN fraction was a single type of protein. Developments in analytical techniques such as ultracentrifugation, chromatography, and electrophoresis helped pave the way for the isolation of the major $\mathrm{CN}$, whey proteins, and minor proteins. It became clear that CN strongly interact with each other under various conditions. This made fractionation of individual components more complicated. Initially, most fractionation focused on treating the acid $\mathrm{CN}$ fraction using various $\mathrm{pH}$, heating conditions, and solvents. It was thought that the whey proteins were just contaminants from blood, and they received little focus initially. It was also thought that reports of other types of proteins in milk may have been the result of decomposition products created from the harsh fractionation methods used (Richmond, 1914). These mistaken beliefs and confusion delayed the complete fractionation of milk proteins.

It was known in 1917 that $\mathrm{CN}$ was acted on by the rennet enzyme with the formation of an insoluble product and that it was the key reaction for cheesemaking (Richmond, 1914). Linderstrøm-Lang (1929) predicted that some protein component helped stabilize the fractions that were insoluble in the presence of calcium and that rennet would hydrolyze this stabilizing component. It took until 1956, when Waugh and von Hippel (1956) identified 2 new fractions called $\alpha_{S^{-}}$and $\kappa-C N$ (which is about $15 \%$ of total CN content), for this stabilizing component to be finally experimentally isolated. In subsequent casein fractionation schemes, $\alpha$-casein became more commonly referred to as $\alpha_{S}$-casein, where "S" in $\alpha_{\mathrm{S}}$ denoted the calcium sensitive fraction. It was not until 1969 that $\alpha_{S}$-CN was further fractionated into $\alpha_{S^{-}}$and $\alpha_{S 2^{-}} \mathrm{CN}$ by Annan and Manson (1969).
Lactalbumin was first identified as a constituent of milk around 1857 by Bouchardat, and the lactoglobulin fraction (now recognized as containing the immunoglobulins) were identified in whey by Sebelien in 1885 (Gordon, 1971). These fractions were eventually shown to be heterogeneous. In 1930, Sjogren and Svedberg crystallized $\alpha$-lactalbumin, and in 1934, Palmer isolated what is now called $\beta$-lactoglobulin (Gordon, 1971). In 1950, Polis and colleagues isolated bovine BSA (Gordon, 1971). The fact that biological proteins could occur in the form of genetic variants was first demonstrated by Aschaffenburg and Drewry (1955), who showed that $\beta$-lactoglobulin has 2 major genetic variants (now called $\mathrm{A}$ and $\mathrm{B}$ ).

In 1972, Groves and colleagues showed that most $\gamma-\mathrm{CN}$ were peptide fragments derived from $\beta$-CN (Groves et al., 1972). That same year, Kaminogawa and colleagues (1972) confirmed that the indigenous protease in milk was plasmin. The origin of the $\gamma$-CN was not fully confirmed until 1979, when Eigel and colleagues demonstrated that hydrolysis of $\mathrm{CN}$ by plasmin was responsible for liberating $\gamma-\mathrm{CN}$ (Eigel et al., 1979). Later it was recognized that plasmin activity became elevated in mastitic and late-lactation milk and that the breakdown of CN contributed to impaired functionality (e.g., softer cheese texture). These findings helped encourage further improvement of milk quality by the reduction in somatic cells. It is now recognized that plasmin may be engaged in several important functions such as regulation of milk secretion, involution processes, defense against invading pathogens, and preventing unwanted CN clotting (Silanikove, 2016).

In 1938, Rowland described a classification method to indicate the overall protein $(\mathrm{N})$ distribution in milk, and he defined proteose peptones and NPN (Rowland, 1938). This type of classification scheme is still (basically) used today in many of the standard methods for the quantification of $\mathrm{CN}$, true protein, and so on. Currently, for the isolation of individual milk proteins, dissociating agents such as urea and SDS are routinely used to reduce the strong tendency of $\mathrm{CN}$ to associate with other $\mathrm{CN}$ as part of their analysis by methods such as electrophoresis.

Physical and Chemical Properties of Proteins. In 1958, Waugh demonstrated that rennet hydrolyzed the newly discovered $\mathrm{k}-\mathrm{CN}$ fraction and produced a soluble peptide (called glycomacropeptide; Waugh, 1958). That research was critical to the development of the mechanism of rennet coagulation of milk, which is the basis of the modern cheesemaking industry. In 1959, Sullivan noted that smaller micelles contained relatively higher $\kappa$-CN contents than larger micelles, leading to the conclusion that the $\kappa-\mathrm{CN}$ content was inversely proportional to the size of micelles (Waugh, 
1971). That helped promote the concept that $\kappa-\mathrm{CN}$ was intimately involved in stabilizing these $\mathrm{CN}$ micelles. Hutton and Patton (1952) indicated that the primary source of sulfhydryl (SH) groups in milk was $\beta$-lactoglobulin and that liberation of this $\mathrm{SH}$ group during heating contributed to the appearance of cooked flavor in severely heated milk. Difficulties in preventing the occurrence of a cooked note in UHT fluid milk products have continued to hinder their popularity in the United States. In 1960, Waugh reported that k-CN contained disulfide bonds but no SH groups (Waugh, 1971), and in 1962 Zittle demonstrated that the heatinduced interaction of $\kappa-\mathrm{CN}$ and $\beta$-lactoglobulin was likely by means of disulfide exchange (Waugh, 1971). For whey proteins, one of the major research focus areas has been the thermal denaturation, unfolding, and aggregation reactions of $\beta$-lactoglobulin. These interactions include disulfide exchange reactions as well as hydrophobic and electrostatic interactions. Heating of milk is widely used as a processing step in the production of concentrates and powders, and a better understanding of heat-induced interactions played an important role in developing powders that were more stable during thermal processing. Many studies have been conducted on improving the stability of whey proteins, such as protein hydrolysis, modification of the mineral content, the addition of chelators, controlling the size of the protein aggregates, enzymatic crosslinking, technologies such as ultrasonication, and protein conjugation with polysaccharides. Improvement in whey protein heat stability has helped enhance the level of protein fortification of foods and beverages.

Whitney in 1961 suggested that the surface of CN micelles was negatively charged; this was subsequently recognized as a key aspect in maintaining the stability of micelles (Waugh, 1971). Jollès in 1966 characterized the sugar group on $\kappa$ - $\mathrm{CN}$ and identified it as $\mathrm{N}$-acetylneuraminic acid (NANA; Waugh, 1971). It was later demonstrated that this NANA group contributed to steric stabilization of the micelle because it protrudes out into the medium and is released by renneting action.

The dissociation of some $\beta-\mathrm{CN}$ into the serum phase when the CN micelle (milk) was cooled was first noticed by Rose (1968) in the 1960s. The preferential dissociation of $\beta-\mathrm{CN}$ at low temperatures has been intensively studied for its effect on milk properties as well as being exploited as a process for the isolation of $\beta-\mathrm{CN}$ as a food ingredient. The modification of the micelle structure upon cooling has been described as "cold aging" or "cold-induced denaturation," and manufacturers learned that these effects were mostly reversible if the cold milk was heated (e.g., by pasteurization). With a decrease in temperature, there is a reduction in calcium binding to the $\mathrm{CN}$ (which could increase local charge repulsion) as well as weakening of the hydrophobic interactions. These factors could be responsible for the release of some $\beta$-CN molecules, which have more of a hydrophobically driven association-type behavior, as well as its lower number of phosphoserine residues than the $\alpha_{S^{-}} \mathrm{CN}$.

The 1970s saw a period during which the AA sequences of all the major milk proteins were reported; this came about because of developments in analytical techniques related to sequencing. Knowledge of the primary sequences of the milk protein allowed for a much greater accuracy of protein composition than classical methods, which were based on solubility under specific conditions and solvents. Elucidation of genetic variants with different AA sequences also led to the discovery that these variants affected milk functionality. These developments also led to the later discovery of the specific genes responsible. Knowledge of the sequence of residues in a protein provides much more insight into the molecular structure than does the AA composition alone (Swaisgood, 2003). One of the first observations that was based on the availability of these sequences was the unique concentration of charged and hydrophobic sequences in separate segments along the protein chain of the CN (Swaisgood, 1973). The hydrophobic character of AA has been experimentally measured (Nozaki and Tanford, 1971) or, more recently, theoretically estimated (Schauperl et al., 2016). Knowledge of the primary structure led to the theoretical calculation of several physical and chemical properties, including prediction of possible ordered structures (Farrell et al., 2013). An ongoing challenge is that there is likely a distinction between the potential (or theoretical) behavior of AA residues and the actual (or likely) in vivo behavior, especially due to the effect of calcium binding on $\mathrm{CN}$ association. It is well known that calcium binding can affect the type of CN structures obtained. For example, sodium caseinate forms elongated rod-like aggregates upon neutralization of acid CN (Lucey et al., 2000), whereas addition of calcium hydroxide results in calcium caseinate forming large spherical (micelle-like) aggregates.

Calcium Binding. In 1917, it was recognized that the milk obtained from different animals had different curd-forming properties (Richmond, 1914) and that these properties related to the degree of phosphate binding to the CN. Although it was understood at that time that calcium and phosphate were associated with $\mathrm{CN}$, the nature of this association was unknown. It is now recognized that milk salts have crucially important effects on many properties of milk (e.g., the formation and stability of the CN micelles, acid-base buffering, and various colligative properties) as well as a key bio- 
logical role (i.e., providing nutrition for the newborn; Lucey and Horne, 2009). The calcium in milk is present at low concentrations as free ions, some as soluble complexes with citrate and phosphate, as well as significant amounts associated with CN micelles (Holt, 1981), called colloidal calcium phosphate (CCP). The behavior of milk proteins during processing is greatly influenced by the mineral content of milk. Acidification, addition of chelating agents, and high-pressure treatment can dissolve the calcium associated with $\mathrm{CN}$ micelles of milk. The $\mathrm{CN}$ are phosphoproteins where phosphorylation occurs at Ser groups. Clusters of phosphorylated groups occur in $\alpha_{\mathrm{S}^{-}}, \alpha_{\mathrm{S}^{-}}$, and $\beta-\mathrm{CN}$, which enhances the calcium binding ability of $\mathrm{CN}$ and facilitates the formation of CCP nanoclusters. $\kappa$-Casein does not have a phosphoseryl cluster and therefore only binds low amounts of calcium. The association of the calcium-sensitive $\mathrm{CN}\left(\alpha_{\mathrm{S}^{-}}, \alpha_{\mathrm{S}^{-}}\right.$, and $\left.\beta-\mathrm{CN}\right)$ and the positioning of the calcium-insensitive $\kappa-\mathrm{CN}$ on the micelle surface is an important factor in the assembly and stability of micelles. A detailed discussion on the physical chemistry of milk salts and their impact on various dairy processes/products can be found in Pyne (1962). The exact nature of the CCP in milk has been the subject of intense debate; more references on this topic can be found in Lucey and Horne (2009). Calcium binding also results in a reduction in the net negative charge on the $\mathrm{CN}$, facilitating their aggregation (Horne, 1982).

Micelle Models. By 1917, it was recognized that the $\mathrm{CN}$ in milk was not in a state of true solution and was present as particles that did not settle out under gravity (Richmond, 1914). It was recognized as far back as 1818 by Schübler that the CN exist in milk as large particles. Initially, these CN particles were usually referred to as "calcium caseinate-calcium phosphate particles," but the term "casein micelle" was introduced in 1921 (but not universally used for several decades more; Fox and Brodkorb, 2008). For example, Jenness (1956) in his review did not refer to CN micelles, instead describing them as "colloidal caseinate particles."

Although researchers were aware of the CN micelle for several decades, there was deep uncertainly about how it was formed and the nature of the interactions responsible for maintaining its stability. Growing knowledge around the properties of the different $\mathrm{CN}$ helped to initiate theories around the type of structure in the CN micelle. In 1956, Waugh and von Hippel, based on detailed studies of how $\mathrm{CN}$ associated with each other, suggested that complexes of $\alpha_{S^{-}} \mathrm{CN}$ and $\beta$-CN could be important preliminary structures involved in the formation of $\mathrm{CN}$ micelles (the concept of core polymers; Waugh, 1971). Shimmin and Hill (1964) published electron micrographs of the CN micelle that showed a surface that was not smooth, and they suggested that the micelle was made up of subunits. Waugh and Noble in 1965 proposed that $\kappa$-CN were located on the micelle surface, forming some type of stabilizing "coat," and that the rest of the micelle (or "core") contained mostly $\alpha_{S^{-}} \mathrm{CN}$ and $\beta$-CN complexes (Waugh, 1971). Morr (1967) proposed a submicelle model in which the subunits were linked by CCP, which builds on Waugh's concept of an outer coat rich in $\kappa-\mathrm{CN}$ and an inner core rich in $\alpha_{S^{-}} \mathrm{CN}$ and $\beta-\mathrm{CN}$ complexes. Morr demonstrated that removal of CCP caused the micelle structure to be disrupted into smaller fragments, and he considered that the smaller fragments were the subunits connected together to make the original micelle.

Horne (1982) demonstrated that the presence of phosphate induced an early aggregation (and precipitation) in mixtures of calcium and $\alpha_{\mathrm{S}_{1}} \mathrm{CN}$, which occurred at very low calcium levels. Because phosphate and calcium should be present in the Golgi apparatus of the mammary cells concurrent to $\mathrm{CN}$ phosphorylation, Horne argued that the micelle assembly process should begin at this early stage (Horne, 1982; Horne et al., 2007). In 1982, Stothart and colleagues using neutron scattering data found an internal structural feature in micelles regularly spaced at about 17 to 18 $\mathrm{nm}$. They interpreted this finding as the actual size of submicelles (Stothart and Cebula, 1982). McGann and colleagues (1983) demonstrated that CCP was present in micelles as approximately 2 - to 3 -nm microgranules. This size did not appear compatible with the smaller type of CCP structure suggested by Schmidt, who used the term "cement" to describe the nature of CCP in micelles (Schmidt, 1983). It was later recognized that this scattering feature in $\mathrm{CN}$ micelles is instead related to the internal spacing between these CCP microgranules (more recently called nanoclusters) within micelles and was not related to the size of any protein subunits such as submicelles (De Kruif and Holt, 2003).

Submicelle models continued to dominate thinking about CN micelles until the 1990s. Holt (1992) suggested a micelle model that could be described as a "tangled web or gel network" made up of $\mathrm{CN}$ chains crosslinked by CCP. This model was further refined in 2003 as the nanocluster model (De Kruif and Holt, 2003). Horne (1998) published the dual-binding model that for the first time explained why, during the formation of the micelle, CN-CN associations did not continue indefinitely until the $\mathrm{CN}$ formed a system-spanning gel. In the dual bonding model for the assembly of the micelle, formation of micelles results from both hydrophobic and electrostatic interactions, with $\kappa-\mathrm{CN}$ acting as a terminator preventing further growth of the micelle. Horne (1998) viewed micelle assembly as a delicate balance between attractive hydrophobic-type interac- 
tions and believed that the formation of CCP (calcium binding) helped neutralize or reduce electrostatic repulsion between phosphoserine groups on $\alpha_{S^{-}} \mathrm{CN}$ and $\beta-\mathrm{CN}$. Because $\kappa-\mathrm{CN}$ does not contain phosphoserine clusters, once it hydrophobically attaches itself to a growing chain of $\alpha_{S}-\mathrm{CN}$ and $\beta-\mathrm{CN}$, the $\kappa-\mathrm{CN}$ is unable to extend the $\mathrm{CN}$ polymerization chain and thus acts as a terminator ending up on the micelle surface.

Choi and colleagues experimentally reported the molar mass of CCP as being around 7,000 g/mol (Choi et al., 2011). Assuming that nanoclusters form a multifaceted solid, such as a tetrahedron- or bipyramid-shaped crystalline entity, it can be calculated that CCP nanoclusters would have a size of around $3 \mathrm{~nm}$ (Horne et al., 2007), in agreement with the experimental evidence from McGann and colleagues (1983) as well as the scattering distance between CCP as reported by De Kruif and Holt (2003). These results are compatible with the model for the CN micelle that involves small $(\sim 3 \mathrm{~nm})$ $\mathrm{CCP}$ nanoclusters as one key type of crosslink between CN.

Nutritional Aspects of Milk Proteins. The nutritional quality of milk proteins has been recently reviewed (Pellegrino et al., 2013). Milk and dairy products contribute a significant proportion of the dietary intake of proteins for children and adults in many western countries. There are many methods for assessing protein quality in terms of supporting body protein metabolism - for example, the biological value, which looks at the proportion of absorbed protein that is retained in the body for maintenance or growth. Milk protein scores $>90 \%$ and whey protein equals $100 \%$ by the biological value index, whereas soy and wheat score only 74 and $64 \%$, respectively. A commonly used index of protein quality is the protein digestibility-corrected AA score. Values higher than $100 \%$ are not accepted as such but rather are truncated to $100 \%$, and a criticism is that many types of protein (including milk protein and soy protein isolate) score at $100 \%$. Other types of quality indicators, such as the digestible indispensable AA score, are currently being investigated. By this method, milk protein scores at $118 \%$, which is much higher than soy protein isolate $(90 \%$; Rutherfurd et al., 2015). One of the major reasons for the higher quality of milk proteins such as whey is their very high concentration of branched-chain AA (26\%), which is higher than any other food protein. Branched-chain AA play roles in many important metabolic functions, including muscle synthesis.

Over the past 20 to $30 \mathrm{yr}$ it has become recognized that many interesting peptides could be released from milk proteins during human digestion or during fermentation of dairy products (Clare and Swaisgood, 2000). These peptides are described as bioactive peptides because they could display a range of physiological effects, including antihypertensive, antimicrobial, and mineral binding effects. There is significant research interest in these peptides because they could provide potential health benefits through the consumption of fermented dairy products such as cheese. Specific cultures or selected enzymes have been used to enhance the levels of these peptides in some dairy products. Isolation or enrichment of bioactive peptides derived from milk proteins could become part of future medical or functional foods (Beltrán-Barrientos et al., 2016). More work is needed for the clear demonstration of health benefits in order for acceptable claims to be approved in the marketplace.

Functionality of Milk Proteins and Development of New Ingredients. In the 1970s and 1980s, there was a major research focus on understanding the key functional properties of dairy proteins, especially whey, and relating functionality to the structure and biological function of these proteins. Many references on this subject can be found in Harper (1981), Mangino (1984), Schmidt et al. (1984), and de Wit (1998). These functional properties include solubility, whipping, foaming, gelation, and emulsification. Developments in separation technologies such as membrane filtration and chromatography were instrumental in taking the new knowledge of the properties of milk proteins and exploiting it into the production of new, higher protein ingredients or purified fractions (Melachouris, 1984; Huffman and Harper, 1999). These new ingredients are now used in a vast range of consumer and nutritional products and have added tremendous value to milk. For whey, these developments took a waste product that was spread on fields or used as animal feed and created a highly sought-after food ingredient. For example, US production of whey protein isolate ( $>90 \%$ protein) is now around 50,000 t. The value of US exports of whey protein concentrate in 2014 was more than $\$ 400$ million. For the creation of whey protein ingredients, the major challenges that had to be overcome were related to denaturation during processing and compositional variability (e.g., due to different cheese types or processing conditions). Functional properties of milk proteins are affected by many variables, including heat treatment, presence of other food components such as sugar, and environmental conditions (e.g., $\mathrm{pH}$ and mineral levels), which makes it difficult to predict their behavior in fabricated food products. Model food systems have been successfully used to better explain and predict milk protein behavior in complex foods (Harper, 1984; de Wit, 1998). Up to the 1960s industrial uses of CN dominated over their use for human consumption purposes. In recent years microfiltration of milk has allowed for the production of $\mathrm{CN}$ concentrates (some- 
times called micellar $\mathrm{CN}$ ) that are depleted in the level of whey (serum) proteins. This approach also generates milk-derived whey that has been shown to have excellent flavor and functional properties.

\section{Milk Fat}

In 1917, it was known that milk fat existed in the form of globules, but the nature of the membrane was not clear. It was also known that most fat existed in the form of triglycerides (Richmond, 1914). Milk contains about 3 to $5 \%$ fat, secreted as droplets or globules roughly 2 to $6 \mu \mathrm{m}$ in diameter, surrounded by a membrane of polar lipids and proteins termed the milk fat globule membrane (MFGM). Milk is an oil-in-water emulsion but not a simple emulsion. Within the core of the fat globule, triacylglycerols are the main molecular form. Minor amounts of diacylglycerols, monoacylglycerols, free fatty acids, polar lipids and sterols, and trace amounts of fat-soluble vitamins and $\beta$-carotene are also present. Fats are synthesized within the mammary epithelial cell and appear as droplets with a membrane layer. These lipid droplets exit the epithelial cells by pushing through the apical membrane and thereby become surrounded by the apical cell membrane. The MFGM is now known to be a complex mixture of proteins, phospholipids, glycoproteins, enzymes (xanthine oxidase and phosphatase), and trace elements such as iron and copper (Mather, 2000). The structure of this MFGM can be easily damaged by shearing, pumping, and agitation and can make the milk susceptible to developing hydrolytic rancidity. In recent years, there has been interest in the nutritional properties of this MFGM.

The first real evidence that milk fat did not comprise simple triglycerides was offered in 1913 by Anlberger (Jack and Smith, 1956). By means of fractional crystallization and isolation of individual glycerides, he was able to separate several mixed glycerides from milk fat. In 1927, Hilditch and Lea developed an oxidation procedure by which the fully saturated glycerides could be separated from those containing unsaturated components. These types of techniques allowed researchers to determine the glyceride composition (fatty acid distribution) of milk fat (Jack and Smith, 1956). The detailed triglyceride structure of milk fat was still not fully clear by the mid-1960s (Jensen and Sampugna, 1966), mainly because of the diversity of fatty acids and the presence of short-chain fatty acids, which complicated the analysis. The general features of the composition of milk fat were known by 1917, including the major types of fatty acids (Richmond, 1914). Improvements in analytical techniques starting in the 1920s helped identify the minor types of fatty acids. The fatty acid composition of milk fat is very complex compared with other dietary fats, and more than 400 different fatty acids have been identified in bovine milk lipids. However, only 13 fatty acids have been detected at concentrations exceeding $1 \%$ (wt/wt). The fatty acids esterified into triacylglycerol are derived either from plasma lipid or by de novo synthesis from small-molecule precursors. In the bovine mammary gland, short- and medium-chain fatty acids (from C4:0 to C14:0 but also some C16:0) are the major products of de novo lipogenesis (synthesis of new molecules from precursors such as BHB), whereas plasma lipids (derived from blood) contribute longer chains and monounsaturated species.

In recent years, the nutritional image of milk fat has undergone a significant reappraisal. Dietary recommendations have focused on reducing saturated fat intake to try to reduce the rates of chronic issues such as cardiovascular disease (CVD) and stroke. This recommendation is based on the oversimplified assumption that all saturated fat intake, including the saturated fat in dairy products, is associated with an increased risk of CVD. Multiple scientific reviews have concluded, based on analysis of extensive published studies, that consumption of dairy products does not elevate the risk for CVD (e.g., Huth and Park, 2012). Several factors could be responsible for this reappraisal. Dairy fat is about $66 \%$ saturated, $30 \%$ monounsaturated, and $4 \%$ polyunsaturated fats, making it a good source of a variety of types of fatty acids that all interact differently within the body. Milk fat contains a significant amount of short- and medium-chain fatty acids that may actually be beneficial. Milk fat is also one of the main dietary sources of CLA that has several potential health benefits. Parodi (1977) was the first to identify cis-9,trans-11 octadecadienoic acid as a fatty acid in milk containing a conjugated bond; this is the major isomer in milk fat.

A recent meta-analysis of 29 studies (Guo et al., 2017) concluded that dairy products containing all fat levels do not increase the risk of coronary heart disease or CVD but rather have a neutral effect on health. Indeed, fermented dairy products may lower the risk of having a heart attack or stroke, and shunning cheese, milk, or yogurt may damage bone development. There have been attempts to alter the fatty acid profile in milk - for example, to increase the proportion of PUFA. These approaches have included genetic selection of cows with higher levels of these fats or use of feeds such as rapeseed oil. The rumen bacteria biohydrogenate unsaturated fats, so strategies such as encapsulation of these unsaturated fats have been used. Feeding can affect the fatty acid profile (Palmquist et al., 1993) for example, when cows are fed exclusively grass, the proportion of C16:0 decreases. Dairy companies now 
produce and market milk with altered fatty acid profiles (achieved by either feeding or genetic selection approaches). Grass-fed cows also tend to produce milk with higher levels of CLA and $\beta$-carotene, providing a more yellow color.

In 1917, there was a limited understanding of the melting properties of milk fat, which are now known to depend on the types and proportions of their esterified fatty acids. Seasonal changes in the amounts of some fatty acids (i.e., oleic and palmitic) can result in winter fat being harder than summer fat, at least in countries where cows take in a significant proportion of their feed as grazing. Knowledge of the melting properties of milk fat has facilitated increased uses, such as the isolation of different melting fractions and the manufacture of new products such as anhydrous milk fat.

\section{Lactose}

In 1917, there was still uncertainty about whether all milks contained lactose; some groups believed that some milks contained different types of sugars (Richmond, 1914). Many references on the historical discoveries about lactose can be found in Whittier (1944). The first records of the crystallization of crude lactose from evaporated whey date back to 1688 , and the first recorded lactose hydrolysis was in 1812 . Confirmation of the composition of this disaccharide and specific types of linkages involved occurred during the second half of the 19th century. The correct structure was determined by Haworth and Long (1927). Mutarotation of lactose between the alpha and beta forms was first noted in 1855. Extensive investigations into mutarotation, solubility, crystallization, and the equilibria between the different forms of lactose were conducted in the first couple of decades of the 20th century, and the state of the basic physical chemistry of this area was summarized by Whittier (1944). Knowledge of the detailed solubility and crystallization behavior was critical in developing lactose products with high purity (e.g., pharmaceutical-grade lactose) because these processes required careful control of refining and crystallization. Lactose crystallization is important for its industrial manufacture, but prevention of its crystallization is important in products such as ice cream or evaporated milk, where it produces a defect known as sandiness. Sweet whey powder is prone to caking during storage as a lactose glass is formed during spray drying. This lactose glass is highly hydroscopic and can absorb moisture from the air during storage, resulting in caking, or clumping, of the powder. This defect can be avoided by precrystallization into the $\alpha$-hydrate form of lactose during the powder manufacturing process but before final drying. Knowledge of the properties of the 2 dif- ferent forms of lactose is exploited in the purification process of lactose. Various crystal forms are produced, including the tomahawk-shaped crystals.

Ebner et al. (1966) discovered that $\alpha$-lactalbumin was part of the lactose synthetase complex and played a vital role in lactose synthesis. This finding explained why lactose is found only in milk, as its synthesis required the milk protein $\alpha$-lactalbumin, which has been identified in the milk of all mammals so far characterized. Lactose is the most abundant component in milk apart from water, and its formation in the mammary gland helps to draw in water from blood to maintain an isosmotic balance. Thus, the lactose level in milk is correlated with milk yield; for example, lactose levels decrease in late-lactation milk as the milk volume declines. Why is lactose the sugar in milk? Lactose provides lower viscosity and is easier to digest compared with polysaccharides, and the selection of a disaccharide such as lactose rather than a monosaccharide such as glucose helps pack in more carbohydrate (energy) within the limit of needing to remain isotonic with blood. Because lactose is a reducing sugar, it contributes to reactions such as Maillard browning, which is frequently observed in sterilized milk. Moreover, lactose can be modified by a multitude of chemical reagents to produce various derivatives (e.g., lactulose, lactitol, and lactobionic acid).

The 1960s also saw the use of high-purity lactose as an excipient in the pharmaceutical industry (Whiteman and Yarwood, 1988). It is ideal as a carrier and stabilizer of aromas and pharmaceutical products due to its chemical inertness, low compressibility, low sweetness, low cost, and low water solubility and hygroscopicity.

Lactose is also the substrate for dairy fermentations such as cheese and yogurt. There is a range of important types of lactic acid bacteria, and many of these species have been originally isolated from fermented milk products. Lactic acid production helps prevent growth of undesirable microorganisms and facilitates gel formation. Lactic acid is also the substrate for carbon dioxide production in Swiss-type cheeses.

\section{Other Milk Components}

In Dairy Chemistry (Richmond, 1914), there was no mention of vitamins. The first vitamin, A, was isolated from milk fat at the University of Wisconsin-Madison by McCollum and Davis (1913). Other vitamins were soon discovered and isolated from a range of foods. Elucidation of the exact chemical structures of vitamins would take several decades. These early feeding studies led to the birth of nutritional science and to the realization that the diet of humans and animals would need more than just fat, carbohydrates, and protein. Steen- 
bock, also from the University of Wisconsin-Madison, discovered that he could increase the amount of vitamin D in foods such as milk by irradiating them with UV light (Steenbock, 1924). He patented his irradiation technique, and this process led to the establishment of the Wisconsin Alumni Research Foundation, one of the first university organizations for the patenting and marketing of faculty inventions. Fortification of milk with isolated vitamin D (concentrates) formally started in 1932. In the 1920s it was estimated that up to $75 \%$ of children in New York City experienced some form of rickets, and in 1933 more than 300 deaths from rickets were reported in the United States (Backstrand, 2002). The problem was worse in the large northeastern cities of the United States, where there was little access to sunlight, as vitamin $\mathrm{D}_{3}$ can be synthesized in skin from 7-dehydrocholesterol (precursor) under the influence of sunlight. It is now estimated that dairy products such as milk contribute more than $60 \%$ of the dietary vitamin $\mathrm{D}$ intake for children, and rickets is no longer a chronic issue in the United States. It is clear that vitamin D fortification of milk helped increase calcium absorption and helped address this childhood bone disorder. Osteoporosis (weakening of bones) is a significant issue as people age, and maintaining sufficient intakes of vitamin D and calcium is widely recognized as essential for bone health. Knowledge of the structure and properties of vitamins has helped dairy processors minimize their losses during processing and storage (e.g., selection of packaging with a light barrier). As skim and lower fat milks became popular, the concomitant reduction of vitamin A levels with fat reduction became an issue because whole milk was considered a good source of vitamin A. The appropriate fortification level of these products was addressed in the 1970s by language in the standards of identity for lowfat and nonfat milks, which state that in these products "vitamin A shall be present in such quantity that each quart of the food contains not less than 2000 International Units thereof within limits of good manufacturing practices" (Pasteurized Milk Ordinance, 2009).

Around 60 indigenous enzymes have been reported in normal (healthy) bovine raw milk. The specific role in milk, if any, for most of these enzymes is still not clear. Their presence in milk can be derived from various sources: leakage from blood, the secretory mammary cell cytoplasm, or the MFGM. There has been significant interest in milk enzymes due to their role in causing product deterioration (e.g., lipase), as indicators of thermal processing (e.g., alkaline phosphatase), as indices of mastitic infection (e.g., catalase), or as a source of antimicrobial activity (e.g., lysozyme). Enzymes in milk can be found in the serum phase, associated with cream or lipids (e.g., MFGM), associated with CN micelles, or present in microsomal particles or leucocytes.

Many references to the historical discoveries of the enzymes in milk can be found in Shahani et al. (1973). Lactoperoxidase was the first enzyme detected in milk (circa 1881; originally it was called peroxydase). Isolation of purified lactoperoxidase was achieved by Thurlow (1925). The destruction of its activity has been used as an index of flash pasteurization of milk. Lactoperoxidase is also a component of the system called cold pasteurization of milk, which has been used in various parts of the world to extend the shelf life of raw milk; the other components of this system include $\mathrm{H}_{2} \mathrm{O}_{2}$ and thiocyanate. Babcock and Russell (1897) suggested that there was an indigenous proteinase in milk, but many others thought that the enzyme might be a contaminant of microbial origin. It is now known that there are at least 2 indigenous proteinases in milk: plasmin and cathepsin D. Plasmin is quite heat stable, and possible residual activity in UHT milk remains a concern because it has been implicated in age gelation of these products. Xanthine oxidase was first demonstrated in milk in 1902, and it is mostly located within the MFGM (Shahani et al., 1973). The significance of xanthine oxidase in milk is that it is a pro-oxidant and thus could contribute to increased oxidation of milk fat (and the occurrence of off flavors such as cardboard or metallic). Alkaline phosphatase started to be routinely used as a regulatory index of adequate pasteurization of milk shortly after it was first observed in milk in 1933. By the 1940s, it was realized that the denaturation of this enzyme was reversible and that reactivation could occur under certain conditions (e.g., higher milk storage temperatures). Fat deterioration during the storage of butter had been noted for a very long time. Esterase activity in milk was noted as early as 1901, whereas lipase activity was demonstrated by 1904 (Shahani et al., 1973). The major lipase in milk is lipoprotein lipase, which is associated with the $\mathrm{CN}$ micelles. The triglycerides are mainly present within fat globules that are protected by the MFGM, and it is when the MFGM is damaged (e.g., by shearing or pumping) that lipolysis occurs as hydrolytic rancidity with the liberation of free fatty acids. Improved knowledge of the mechanisms involved in rancidity has resulted in significant changes to aspects such as the design of milking equipment, attention to the proper operation (and selection) of pumps (to reduce air incorporation), and the use of more severe heat treatments for products such as cream to inactivate most lipase.

The presence of hormones in milk was first described by Yaida (1929). At that time there was no knowledge about why they were in milk and their possible roles. Hormones found in milk can originate from blood 
and are then actively transported into the mammary gland, or some hormones are synthesized in the mammary gland and are then excreted into milk. Forms of hormones include those of steroidic or peptidic origin. These hormones are involved in regulation of specific functions of the mammary gland or contribute to the growth of the newborn (Jouan et al., 2006). These substances include prolactin, growth factors, insulin, progesterone, and cortisol. Hormones play a key role in triggering the development of the mammary gland as well as other important aspects, such as the fertility of the cow. It is not clear whether the presence of very low levels of these hormones in bovine milk has any health benefits for humans. It should be noted that the human body itself secretes more than 50 types of hormones or chemical messengers. In 1993, the FDA approved the use of bST to increase milk production, and a key factor in their decision was based on studies showing that bST was safe and that, because bST is a peptide-derived hormone, it would be digested in any milk or meat product consumed. In recent years, with the growing consumer interest related to products that can be labeled as "free from," the popularity of bST use by farmers has decreased.

A minor class of sugars observed in milk is the oligosaccharides. These sugars are not degraded by bovine digestive enzymes but instead act as prebiotics to selectively support growth of specific commensal microbial populations and to prevent the adhesion to pathogens to the epithelial surface of the intestine. Unlike lactose, these carbohydrates are defined as having between 3 and 9 monosaccharide units covalently linked through glycosidic bonds, usually with lactose as the core monosaccharide, and are classified as either neutral or sialyl (acidic) oligosaccharides depending on their saccharide units. Oligosaccharides are produced by the activity of $\beta$-galactosidase. The first reported sialyl oligosaccharides from bovine colostrum appeared in 1956 (Kuhn and Brossmer, 1956), and the first bovine milk neutral oligosaccharides were reported by Saito et al. (1984). The concentrations of oligosaccharides in bovine milk are low compared with human milk but may be harvested from the whey stream for use in infant formula and other dairy products.

Lactose can be enzymatically hydrolyzed using $\beta$-galactosidase to produce low-lactose or lactosefree dairy products. Under certain conditions, the $\beta$-galactosidase enzyme also has transferase reactivity by which it produces, and subsequently hydrolyses, a series of oligosaccharides containing galactose (galactooligosaccharides; Aronson, 1952). Apart from theoretical aspects, early research was prompted by nutritional concerns about the presence of these compounds in low-lactose milk. Other later studies were based on the need to consider oligosaccharide formation when modeling lactose hydrolysis. More recently, interest in the reaction has been raised by the observation that oligosaccharides may have beneficial effects as bifidus factors that promote the growth of desirable intestinal microflora and have been added as a prebiotic in dairy products such as infant formula. Also, the transferase reaction can be used to attach galactose to other chemicals and consequently has potential applications in the production of food ingredients, pharmaceuticals, and other biologically active compounds.

\section{Physical Equilibria and Chemistry of Milk}

The concept of $\mathrm{pH}$ was only introduced in 1909. With the advent of glass electrodes that came into general use by the $1930 \mathrm{~s}$, pH determinations became commonplace for milk and dairy products. Titratable acidity was widely used to estimate whether milk had soured and involved the titration of milk to the phenolphthalein endpoint ( $\mathrm{pH}$ 8.3). However, higher protein levels increase buffering and thus result in elevated titratable acidity results (but not because of souring). The acidbase equilibria were a major focus in dairy chemistry in the 1920 s to 1930 s, but this topic was complicated by the diverse range of salts such as phosphate, citrate, and bicarbonates. It was also recognized that a proportion of phosphate and calcium was present within the CN micelles. It took until the 1990s to clearly recognize that the acid-base buffering properties of milk and dairy products were dependent on whether the buffering behavior was being determined during acidification or alkalization processes (Lucey and Fox, 1993). During acidification, milk exhibits a buffering peak around $\mathrm{pH} 5$ due to the release of phosphate ions from CCP, whereas during alkalization of milk calcium phosphate precipitation occurs around $\mathrm{pH} 6$ (releasing hydrogen ions and thereby decreasing $\mathrm{pH}$ ).

The freezing point of milk varies little with changes in the concentration of components such as fat and protein because milk is isotonic with blood. The development of the cryoscopy method by Hortvet (1921), and its optimization by later groups, facilitated the routine use of this test for the detection of added water (adulteration; Shipe, 1959). The concentration of soluble components such as lactose and salts such as chloride is the major contributor to the freezing point. Many studies in the following decades evaluated the effect of feed, seasonality, breed, and so on, on the freezing point of milk; the observed small differences were partly attributable to some discrepancies with the analytical methods.

A major topic of research on the physical and chemical properties of milk that recurs again and again throughout the past century is heat-induced coagula- 
tion. Heat-induced coagulation and its related subject, milk quality, were important in the 1920s because of problems encountered in the production of sterilized evaporated milk (Sommer and Hart, 1922). Producers adopted ad hoc methods manipulating the concentrations of milk minerals to overcome these problems, based partly on observations by Sommer and Hart (1922) on the importance of salt balance, though reliable methods of measuring some mineral concentrations were still unavailable and many reports around this time were concerned with influences of acidity and its development. Alcohol stability tests were also suggested as a possible indicator of the resistance to heat-induced coagulation at this time.

In the early 1960s, Rose (1961) further revealed the complexity of heat stability when he demonstrated a $\mathrm{pH}$ sensitivity curve with a maximum and minimum and a dependence on $\beta$-lactoglobulin content. White and Davies (1966) showed that within the minimum, heated milk underwent a 2-step coagulation, meaning that 2 mutually exclusive precipitation processes were occurring. With suitable methodology for determining ionic calcium levels in milk now available, Davies and White (1958) found a correlation between heat stability at natural $\mathrm{pH}$, alcohol stability, and ionic calcium content. In the 1980s, Horne and Parker (Horne and Muir, 1990) found that alcohol stability also showed $\mathrm{pH}$ sensitivity and that the position of the stability versus $\mathrm{pH}$ profile depended on ionic calcium level. Horne and Muir (1990) later summarized these data in a review that reconciled alcohol and heat stability behavior.

Heat stability and resistance to heat-induced coagulation of milk continues to be a persistent problem today in developing markets in Central and South America where UHT processing is now the norm. Alcohol tests are still used with varying success and many milks are rejected, possibly on dubious grounds. Heat stability problems are also encountered in production of energyintensive, high-fat, high-protein preparations for specialist nutritional beverages and appear to be overcome by the age-old salt balance methodology.

Several reviews have discussed how knowledge of milk protein chemistry can be used to understand the various reactions involved in the dairy processing industry; references can be found in Morr (1975), Harper (1981), de Wit (1998), and Augustin and Udabage (2007). These processes include heat, shear, fermentation, high pressure, freezing, changes in water activity, and changes in the ionic environment. Key reactions include denaturation, aggregation, gelation, enzyme inactivation, Maillard reactions, and vitamin destruction.

Knowledge of dairy chemistry has also been important for improving milk quality, including the occurrence of off flavors. For example, the negative effect of light on the flavor of milk products has been reported as far back as 1890 and was a major concern in the early 1930s with the advent of the use of UV radiation of milk to enhance vitamin D levels (later replaced by the fortification of synthesized vitamin $\mathrm{D}$ directly in milk). But the exact nature of this defect ("sunlight" or "burnt") was not finally elucidated until Patton (1954) showed that sunlight catalyzed an oxidation reaction of Met to methional and that this reaction required riboflavin. These findings helped shift packaging of milk from clear glass bottles to containers such as cartons that include light-blocking materials or layers.

\section{SUMMARY AND FUTURE DIRECTIONS}

The past $100 \mathrm{yr}$ have seen tremendous advances in identifying the diverse array of components in milk, including the main types of milk proteins. Developments in analytical techniques have helped fractionate as well as characterize milk components. Knowledge of the biosynthesis of milk components has rapidly progressed over the past $50 \mathrm{yr}$. Milk testing has also been transformed from a slow procedure done in the laboratory to rapid testing of multiple components that can be done at the farm. The nature and structure of the CN micelle has been intensively studied, and the main types of interactions and the basic model for the structure have been clarified. Much work remains to be done to fully understand the exact types of interactions between CN. Improved knowledge of the main types of milk proteins facilitated the commercialization of new milk protein ingredients that are increasingly sought after in nutritional applications. There will be a continued focus on understanding the biological purpose and nutritional aspects of milk components using a range of powerful techniques, including -omics, model cell lines, analysis of the gut microbiome, and imaging methods.

The detailed composition of milk and its key physical and chemical properties are now well known. A strong focus will remain on how the unique structures of milk components affect their biological purpose (i.e., nutrition for the neonate). Examples of these interesting components and segments include the $\mathrm{CN}$ micelle, bioactive peptides, MFGM, and oligosaccharides. It is now recognized that processing and structuring of food affects its digestibility. Any successful attempts to design dairy food structures with health benefits will have to take the digestion step and bioavailability into account. Some of the key interactions responsible for the formation and stability of the $\mathrm{CN}$ micelle are now partly understood, and in the future more focus will be on fully understanding these interactions to design products as well as improve the stability and functionality of milk protein ingredients. More modified 
dairy ingredients are likely to be produced by modulating CCP levels, utilizing enzymatic crosslinking, or exploiting membrane filtration or other fractionation techniques. Perhaps future researchers can create designer milks that are enhanced with certain diseasepreventing components or that lack proteins that cause cow milk protein allergy. Perhaps genetic selection of cows using modern genomic approaches can help shift the composition of bovine milk to become closer to that of human milk, which could be of interest for the growing use of dairy ingredients in health and nutritional products. These novel ingredients or products would still require heat treatment or nonthermal processing to address food safety concerns. For some heat-sensitive components, alternative processing techniques will be needed to preserve bioactivity.

Our ancestors were ignorant of the existence of $\kappa$-CN and its critical role in stabilizing $\mathrm{CN}$ micelles, but that did not prevent them from developing cheese manufacture. Lack of knowledge of the structure of the $\mathrm{CN}$ micelle did not inhibit production of dried milk powders, nor was it necessary for our forefathers to know the structure of the MFGM to make butter. The research documented over the past $100 \mathrm{yr}$ has filled in the jigsaw puzzle that is milk composition, how the components are organized, and how the CN proteins are assembled in the CN micelle. All of that is moving us forward in a quest to make the production of existing products more efficient and sustainable and to innovate the development of new outlets for milk and its components.

In the case of the $\mathrm{CN}$ micelle, we appear to be in a position where we know the structure but are still speculating on the interactions that give rise to that structure. That debate is heating up. We can provide broad pictures of the mechanisms of rennet coagulation or destabilization by heat, acid, or alcohol, but quantification of reaction rates or identification of the influences of what might be minor changes in milk composition still escape us. Understanding the interactions between the proteins, whether in micelles or as separated species, will take our ability to control the aforementioned reactions to a new level. However, unrealistic model systems could lead to erroneous conclusions. Knowing whether or how particular groups or side chains interact could allow tailoring of production of specified flavor components in cheese or the construction of desired textures. The study of the effects of milk protein genetic variants on rennet coagulation flared briefly and died quickly in the early 1990s. Perhaps the nuances introduced by those variants would be better understood and exploited with greater quantitative knowledge of protein interactions.

Milk testing has evolved from gross compositional testing for regulatory purposes or farm payments to a diverse range of tests that are used for purposes such as farm management and animal health. Testing traditionally was done in large centralized laboratories and increasingly will move to the farm itself. Approaches such as ELISA are now used to indicate the likely presence of Johne's disease in cow milk, and these techniques are already helping farmers with data to take action to reduce incidence of this disease. Another example of diagnostic testing is PCR, which is now being used to help identify the causative bacteria for mastitis. These data have helped farmers identify chronic shedders of pathogens and make management decisions to remove these specific animals and thereby reduce SCC levels. Currently more than 30 tests (compositional and indicator) can be done on milk samples, and it is likely that the number of useful tests will keep increasing. Increasing technology such as robotic milking systems will also make collecting and testing milk samples easier. More on-farm milk testing will continue in the future because this provides more timely data for farmers to make management decisions and because the milk collection process is easier than sampling blood or other biological materials.

\section{ACKNOWLEDGMENTS}

The authors gratefully acknowledge the funding support to the Center for Dairy Research by the Wisconsin Milk Marketing Board (Madison, WI) and National Dairy Council (Rosemont, IL). The authors are grateful to the very many colleagues, friends, collaborators, and students they have worked with over the yearstoo many to mention but they all know who they are. Without them, our knowledge of dairy chemistry would be much poorer.

\section{REFERENCES}

Annan, W. D., and W. Manson. 1969. A fractionation of the $\alpha_{\mathrm{s}}$-casein complex of bovine milk. J. Dairy Res. 36:259-268.

Aronson, M. 1952. Transgalactosidation during lactose hydrolysis. Arch. Biochem. Biophys. 39:370-378.

Aschaffenburg, R., and J. Drewry. 1955. Occurrence of different betalactoglobulins in cow's milk. Nature 176:218-219.

Augustin, M. A., and P. Udabage. 2007. Influence of processing on functionality of milk and dairy proteins. Adv. Food Nutr. Res. $53: 1-38$.

Babcock, S. M., and H. L. Russell, 1897. Unorganized ferments of milk: A new factor in the ripening of cheese. Agr. Res. Stat. UWMadison, 14th Ann. Rep. 161-193. University of Wisconsin, Madison.

Backstrand, J. R. 2002. The history and future of food fortification in the United States: A public health perspective. Nutr. Rev. 60:1526.

Bauman, D. E., I. H. Mather, R. J. Wall, and A. L. Lock. 2006. Major advances associated with the biosynthesis of milk. J. Dairy Sci. 89:1235-1243.

Beltrán-Barrientos, L. M., A. Hernández-Mendoza, M. J. TorresLlanez, A. F. González-Córdova, and B. Vallejo-Córdoba. 2016. 
Fermented milk as antihypertensive functional food. J. Dairy Sci. 99:4099-4110.

Brunner, R. J. 1981. Cow milk proteins: Twenty-five years of progress. J. Dairy Sci. 64:1038-1054.

Choi, J., D. S. Horne, and J. A. Lucey. 2011. Determination of molecular weight of a purified fraction of colloidal calcium phosphate derived from the casein micelles of bovine milk. J. Dairy Sci. 94:3250-3261.

Clare, D. A., and H. E. Swaisgood. 2000. Bioactive milk peptides: A prospectus. J. Dairy Sci. 83:1187-1195.

Clarenburg, R., and I. L. Chaikoff. 1966. Origin of milk cholesterol in the rat: dietary versus endogenous sources. J. Lipid Res. 7:27-37.

Davies, D. T., and J. C. D. White. 1958. The relationship between the chemical composition of milk and the stability of the caseinate complex. II. Coagulation by ethanol. J. Dairy Res. 25:256-266.

De Kruif, C. G., and C. Holt. 2003. Casein micelle structure, functions and interactions. Pages 233-276 in Advanced Dairy Chemistry, Vol. 1: Proteins. 3rd ed. P. F. Fox and P. L. H. McSweeney, ed. Kluwer Academic, Dordrecht, the Netherlands.

de Wit, J. N. 1998. Nutritional and functional characteristics of whey proteins and their products. J. Dairy Sci. 81:597-608.

Ebner, K. E., W. L. Denton, and U. Brodbeck. 1966. The substitution of $\alpha$-lactalbumin for the B protein of lactose synthetase. Biochem. Biophys. Res. Commun. 24:232-236.

Eigel, W. N., C. J. Hofmann, B. A. K. Chibber, J. M. Tomich, T. W Keenan, and E. T. Mertz. 1979. Plasmin-mediated proteolysis of casein in bovine milk. Proc. Natl. Acad. Sci. USA 76:2244-2248.

Farrell, H. M., Jr. 1973. Models for casein micelle formation. J. Dairy Sci. 56:1195-1206.

Farrell, H. M., Jr., E. M. Brown, and E. L. Malin. 2013. Higher order structures of the caseins: A paradox? Pages 161-184 in Advanced Dairy Chemistry, Vol. 1A: Proteins: Basic Aspects. 4th ed. P. L. H. McSweeney and P. F. Fox, ed. Springer Science + Business Media New York, NY.

Farrell, H. M., Jr., R. Jimenez-Flores, G. T. Bleck, E. M. Brown, J. E. Butler, L. K. Creamer, C. L. Hicks, C. M. Hollar, K. F. Ng-KwaiHang, and H. E. Swaisgood. 2004. Nomenclature of the proteins of cows' milk - Sixth revision. J. Dairy Sci. 87:1641-1674.

Fox, P. F., and A. Brodkorb. 2008. The casein micelle: Historical aspects, current concepts and significance. Int. Dairy J. 18:677-684.

Gordon, W. G. 1971. $\alpha$-Lactalbumin. Pages 331-365 in Milk Proteins, Chemistry and Molecular Biology. Vol. 2. H. A. McKenzie, ed. Academic Press, New York, NY.

Groves, M. L., W. G. Gordon, E. B. Kalan, and S. B. Jones. 1972. Composition of bovine $\gamma$-caseins $\mathrm{A}^{1}$ and $\mathrm{A}^{3}$, and further evidence for a relationship in biosynthesis of $\gamma$ - and $\beta$-caseins. J. Dairy Sci. 55:1041-1049.

Guo, J., A. Astrup, J. A. Lovegrove, L. Gijsbers, D. I. Givens, and A. S. Soedamah-Muthu. 2017. Milk and dairy consumption and risk of cardiovascular diseases and all-cause mortality: Dose-response meta-analysis of prospective cohort studies. Eur. J. Epidemiol. 32:269-287.

Harper, W. J. 1981. Advances in chemistry of milk. J. Dairy Sci. 64:1028-1037.

Harper, W. J. 1984. Model food system approaches for evaluating whey protein functionality. J. Dairy Sci. 67:2745-2756.

Haugaard, G., and J. D. Pettinati. 1959. Photometric milk fat determination. J. Dairy Sci. 42:1255-1275.

Haworth, W. N., and C. W. Long. 1927. The constitution of disaccharides. Part XII. Lactose. J. Chem. Soc. 1927:544-548.

Holt, C. 1981. Some principles determining salt composition and partitioning of ions in milk. J. Dairy Sci. 64:1958-1964.

Holt, C. 1992. Structure and stability of bovine casein micelles. Adv. Protein Chem. 43:63-151.

Horne, D. S. 1982. Calcium-induced precipitation of $\alpha_{\mathrm{S} 1}$-casein: Effect of inclusion of citrate or phosphate. J. Dairy Res. 49:107-118.

Horne, D. S. 1998. Casein interactions: Casting light on the black boxes, the structure in dairy products. Int. Dairy J. 8:171-177.

Horne, D. S. 2006. Casein micelle structure: Models and muddles. Curr. Opin. Colloid Interface Sci. 11:148-153.
Horne, D. S., J. A. Lucey, and J. Choi. 2007. Casein interaction: Does the chemistry really matter? Pages 155-166 in Food Colloids: Self Assembly and Material Science. E. Dickinson and M. Leser, ed. Royal Society of Chemistry, Cambridge, UK.

Horne, D. S., and D. D. Muir. 1990. Alcohol and heat stability of milk protein. J. Dairy Sci. 73:3613-3626.

Hortvet, J. 1921. The cryoscopy of milk. J. Ind. Eng. Chem. 13:198 208

Howe, P. E. 1921. An effect of the ingestion of colostrum upon the composition of the blood of new-born calves. J. Biol. Chem. 49:115-118.

Huffman, L. M., and W. J. Harper. 1999. Maximizing the value of milk through separation technology. J. Dairy Sci. 82:2238-2244.

Huth, P. J., and K. M. Park. 2012. Influence of dairy product and milk fat consumption on cardiovascular disease risk: A review of the evidence. Adv. Nutr. 3:266-285.

Hutton, J. T., and S. Patton. 1952. The origin of sulfhydryl groups in milk proteins and their contributions to "cooked" flavor. J. Dairy Sci. 35:699-705.

Jack, E. L., and L. M. Smith. 1956. Chemistry of milk fat: a review. J. Dairy Sci. 39:1-25

Jenness, R. 1956. Progress in the basic chemistry of milk. J. Dairy Sci 39:651-656.

Jenness, R., B. L. Larson, T. L. McMeekin, A. M. Swanson, C. H. Whitnah, and R. McL. Whitney. 1956. Nomenclature of the proteins of bovine milk. J. Dairy Sci. 39:536-541.

Jensen, R. G., and J. Sampugna. 1966. Triglyceride structure of cow's milk fat. A review. J. Dairy Sci. 49:460-468.

Jouan, P.-N., Y. Pouliot, S. F. Gauthier, and J.-P. Laforest. 2006. Hormones in bovine milk and milk products: A survey. Int. Dairy J. 16:1408-1414.

Kaminogawa, S., H. Mizobuchi, and K. Yamauchi. 1972. Comparison of bovine milk protease with plasmin. Agric. Biol. Chem. 36:21632167.

Kuhn, R., and R. Brossmer. 1956. Über O-acetyllactaminsäure lactose aus kuh colostrum und ihre spaltbarkeit durch influenza virus. Chem. Ber. 89:2013-2025.

Kumosinski, T. F., E. M. Brown, and H. M. Farrell Jr.. 1993. Three dimensional molecular modeling of the bovine caseins: An energyminimized $\beta$-casein structure. J. Dairy Sci. 76:931-945.

Linderstrøm-Lang, K. 1929. Studies on casein. III. On the fractionation of casein. Compt. Rend. Rav. Lab. Carlsberg. Ser. Chim. $17: 1-116$

Lucey, J. A. 2002. Formation and physical properties of milk protein gels. J. Dairy Sci. 85:281-294

Lucey, J. A., and P. F. Fox. 1993. Importance of calcium and phosphate in cheese manufacture: A review. J. Dairy Sci. 76:1714-1724.

Lucey, J. A., and D. S. Horne. 2009. Milk salts: Technological significance. Pages 351-389 in Advanced Dairy Chemistry 3. Lactose, Water, Salts and Minor Constituents. 3rd ed. P. L. H. McSweeney and P. F. Fox, ed. Springer, New York, NY.

Lucey, J. A., M. Srinivasan, H. Singh, and P. A. Munro. 2000. Characterization of commercial and experimental sodium caseinates by multi-angle laser light scattering and size-exclusion chromatography. J. Agric. Food Chem. 48:1610-1616.

Mangino, M. E. 1984. Physicochemical aspects of whey protein functionality. J. Dairy Sci. 67:2711-2722.

Mather, I. H. 2000. A review and proposed nomenclature for major proteins of the milk-fat globule membrane. J. Dairy Sci. 83:203247

McCollum, E. V., and M. Davis. 1913. The necessity of certain lipins in the diet during growth. J. Biol. Chem. 15:167-175.

McGann, T. C. A., W. Buchheim, R. D. Kearney, and T. Richardson. 1983. Composition and ultrastructure of colloidal phosphatecitrate complexes in bovine milk systems. Biochim. Biophys. Acta 760:415-420

Melachouris, N. 1984. Critical aspects in development of whey protein concentrate. J. Dairy Sci. 67:2693-2700.

Mellander, O. 1939. Elektrophoretische untersuchung von casein. Biochim. Zeit. 300:240-245. 
Morr, C. V. 1967. Effect of oxalate and urea upon ultracentrifugation properties of raw and heated skimilk casein micelles. J. Dairy Sci. 50:1744-1751.

Morr, C. V. 1975. Chemistry of milk proteins in processing. J. Dairy Sci. 58:977-984.

Nitschmann, H. 1949. Elektronenmikrokopische grössenbestimmung der calciumcaseinatteilchen in kuhmilch. Helv. Chim. Acta 32:1258-1264.

Nozaki, Y., and C. Tanford. 1971. The solubility of amino acids and two glycine peptides in aqueous ethanol and dioxane solutions. Establishment of a hydrophobicity scale. J. Biol. Chem. 246:22112217.

Palmquist, D. L., A. D. Beaulieu, and D. M. Barbano. 1993. Feed and animal factors influencing milk fat composition. J. Dairy Sci. 76:1753-1771.

Parodi, P. W. 1977. Conjugated octadecadienoic acids of milk fat. J. Dairy Sci. 60:1550-1553.

Pasteurized Milk Ordinance. 2009. Grade "A" pasteurized milk ordinance, 1978 revision. US Department of Health and Human Services, Public Health Service, Food and Drug Administration, Washington, DC.

Patton, S. 1954. The mechanism of sunlight flavor formation in milk with special reference to methionine and riboflavin. J. Dairy Sci. $37: 446-452$.

Pellegrino, L., F. Masotti, S. Cattaneo, J. A. Hogenboom, and I. de Noni. 2013. Nutritional quality of milk proteins. Pages $515-538$ in Advanced Dairy Chemistry, Vol. 1A. Proteins: Basic Aspects. 4th ed. P. L. H. McSweeney and P. F. Fox, ed. Springer, New York, NY.

Pyne, G. T. 1962. Some aspects of the physical chemistry of the salts of milk. J. Dairy Res. 29:101-130.

Reinhardt, T. A., and J. D. Lippolis. 2006. Bovine milk fat globule membrane proteome. J. Dairy Res. 73:406-416.

Richmond, H. D. 1914. Dairy Chemistry. 2nd ed. Griffin, London, United Kingdom

Rose, D. 1961. Factors affecting the $\mathrm{pH}$ sensitivity of the heat stability of milk from individual cows. J. Dairy Sci. 44:1405-1413.

Rose, D. 1968. Relation between micellar and serum casein in bovine milk. J. Dairy Sci. 51:1897-1902.

Rowland, S. J. 1938. The determination of the nitrogen distribution in milk. J. Dairy Res. 9:42-46.

Rutherfurd, S. M., A. C. Fanning, B. J. Miller, and P. J. Moughan. 2015. Protein digestibility-corrected amino acid scores and digestible indispensable amino acid scores differentially describe protein quality in growing male rats. J. Nutr. 145:372-379.

Saito, T., T. Itoh, and S. Adachi. 1984. Presence of two neutral disaccharides containing $\mathrm{N}$-acetylhexosamine in bovine colostrum as free forms. Biochim. Biophys. Acta 801:147-150.

Schauperl, M., M. Podewitz, B. J. Waldner, and K. R. Liedl. 2016. Enthalpic and entropic contributions to hydrophobicity. J. Chem. Theory Comput. 12:4600-4610.

Schmidt, D. G. 1983. Association of caseins and casein micelle structure. Pages 61-86 in Developments in Dairy Chemistry, Vol. 1. Proteins. P. F. Fox, ed. Applied Science, London, UK.

Schmidt, R. H., V. S. Packard, and H. A. Morris. 1984. Effects of processing on whey protein functionality. J. Dairy Sci. 67:2723-2733.
Shahani, K. M., W. J. Harper, R. G. Jensen, R. M. Parry Jr., and C. A. Zittle. 1973. Enzymes in bovine milk: A review. J. Dairy Sci 56:531-543.

Shimmin. P. D., and R. D. Hill. 1964. An electron microscope study of the internal structure of casein micelles. J. Dairy Res. 31:121-123.

Shipe, W. H. 1959. The freezing point of milk. A review. J. Dairy Sci 42:1745-1762

Silanikove, N. 2016. Transcellular route as the most probable explanation for the presence of plasminogen in mammal's milk. J. Theor. Biol. 395:221-226.

Sommer, H. H., and E. B. Hart. 1922. The heat coagulation of milk. J. Dairy Sci. 5:525-543.

Sorensen, M., and S. P. L. Sorensen. 1939. The proteins in whey. C. R. Trav. Lab. Carlsberg 23:55-99.

Steenbock, H. 1924. The induction of growth promoting and calcifying properties in ration by exposure to light. Science 60:224-225.

Stothart, P. H., and D. J. Cebula. 1982. Small-angle neutron scattering of bovine casein micelles and sub-micelles. J. Mol. Biol. 160:391-395.

Swaisgood, H. E. 1973. The caseins. CRC Crit. Rev. Food Technol. $3: 375-414$

Swaisgood, H. E. 1993. Review and update of casein chemistry. J. Dairy Sci. 76:3054-3061.

Swaisgood, H. E. 2003. Chemistry of the caseins. Pages 139-201 in Advanced Dairy Chemistry, Vol. 1: Proteins. 3rd ed. P. F. Fox and P. L. H. McSweeney, ed. Kluwer Academic, Dordrecht, the Netherlands.

Tao, N., E. J. DePeters, S. Freeman, J. B. German, R. Grimm, and C. B. Lebrilla. 2008. Bovine milk glycome. J. Dairy Sci. 91:3768-3778.

Thurlow, S. 1925. Studies on xanthine oxidase. IV. Relation of xanthine oxidase and similar oxidizing systems to Bach's oxygenase. Biochem. J. 19:175-187.

Walstra, P. 1990. On the stability of casein micelles. J. Dairy Sci 73:1965-1979

Walstra, P., V. A. Bloomfield, G. J. Wei, and R. Jenness. 1981. Effect of chymosin action on the hydrodynamic diameter of casein micelles. Biochim. Biophys. Acta 669:258-259.

Waugh, D. F. 1958. The interactions of $\alpha_{\mathrm{s}^{-}}, \beta$ - and $\kappa$-caseins in micelle formation. Faraday Soc. 25:186-192.

Waugh, D. F. 1971. Formation and structure of casein micelles. Pages 3-85 in Milk Proteins, Chemistry and Molecular Biology. Vol. 2. H. A. McKenzie, ed. Academic Press, New York, NY.

Waugh, D. F., and P. H. von Hippel. 1956. К-casein and the stabilization of casein micelles. J. Am. Chem. Soc. 78:4576-4582.

White, J. C. D., and D. T. Davies. 1966. The stability of milk protein to heat. III. Objective measurement of the heat stability of milk J. Dairy Res. 33:93-102.

Whiteman, M., and R. J. Yarwood. 1988. The evaluation of six lactose-based materials as direct compression tablet excipients. Drug Dev. Ind. Pharm. 14:1023-1040.

Whittier, E. O. 1944. Lactose and its utilization: A review. J. Dairy Sci. 27:505-537.

Yaida, N. 1929. Ovarial hormone in blood of pregnant women, of pregnant animals; ovarial hormone in urine of pregnant women; ovarial hormone in milk of pregnant animals. Trans. Jpn. Pathol. Soc. 19:39-101. 


\section{APPENDIX}

Table A1. Major milestones in the chemistry of milk and its components

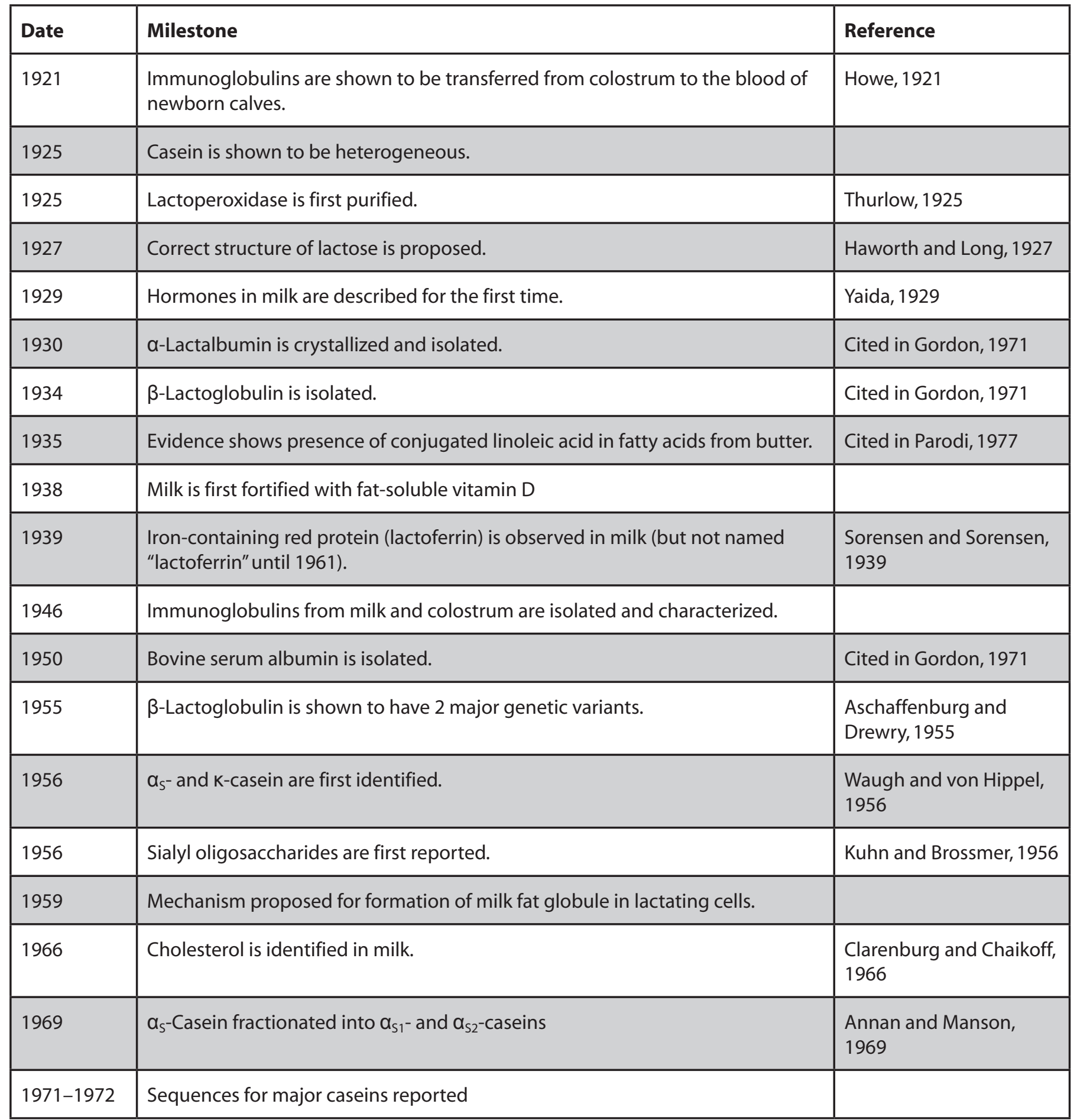


Table A1 (Continued). Major milestones in the chemistry of milk and its components

\begin{tabular}{|l|l|l|}
\hline Date & Milestone & Reference \\
\hline 1977 & The conjugated linoleic acid cis-9,trans-11 C18:2 is characterized. & Parodi, 1977 \\
\hline 1978 & Skim and low-fat milks are first fortified with vitamin A. & \\
\hline 1998 & $\begin{array}{l}\text { Dual-bonding model for micelle assembly is proposed, explaining how K-casein } \\
\text { acts as a chain polymerization terminator, and thus obtains a surface location. }\end{array}$ & Horne, 1998 \\
\hline 2002 & $\begin{array}{l}\text { Docosahexaenoic acid (DHA) and arachidonic acid (ARA) are first added to } \\
\text { infant formula. }\end{array}$ & \\
\hline 2006 & $\begin{array}{l}\text { Milk fat globule membrane proteome is published. } \\
\text { Bovine milk glycome is published. }\end{array}$ & $\begin{array}{l}\text { Reinhardt and Lippolis, } \\
2006\end{array}$ \\
\hline 2009 & $\begin{array}{l}\text { Metabolomics analysis of bovine milk using liquid chromatography-mass } \\
\text { spectrometry. }\end{array}$ & Tao et al., 2008 \\
\hline
\end{tabular}

